\title{
A LOOK INSIDE COOPERATION BETWEEN PROSECUTORS AND LAW ENFORCEMENT DURING CRIME SCENE INVESTIGATION
}

\section{Dževad Mahmutović ${ }^{1}$ Berina Huskanović}

Faculty of Law, University of Tuzla, Bosnia and Herzegovina

\author{
Original scientific paper \\ DOI:10.21554/hrr.091708
}

Received: 04.08.2017

Accepted: 08.09.2017

\begin{abstract}
The paper deals with crime scene investigation as a measure of inquiry, conceptually and substantially, subjects of investigation, as well as their mutual relations. The analysis of the existing legal framework suggests that the current Criminal Procedure Code of Bosnia and Herzegovina offers the appropriate basis for the cooperation between prosecutors and law enforcement. However, previous practice indicates certain shortcomings in the cooperation and coordination between prosecutors and law enforcement. With this paper, the authors wanted to examine the opinions of direct actors on this matter. The results show that they are satisfied with the legal regulation of their mutual relations during investigations, and they express positive opinions in terms of their cooperation. Of course, the possibility of improving that cooperation is also noted, and the methods of achieving it should be identified in further research. ${ }^{2}$
\end{abstract}

Key words: crime scene investigation, law enforcement, prosecutor

\section{INTRODUCTION}

Conceptual and substantive definition of crime scene investigation

Theoretically, there is not a unique definition of crime scene investigation. It is not surprising if we take into consideration the fact that it is a composite investigation with complex law-enforcement matter (Petrović, 2006, p. 115). However, "they can be divided into those which from the law enforcement and criminal-procedural aspect define the term 'crime scene investigation'” (Milidragović, 2008, p.72).

\footnotetext{
${ }^{1}$ Correspondence to:

Dževad Mahmutović, PhD, Assistant Professor, Faculty of Law, University of Tuzla, Bosnia and Herzegovina

Aleja A. Izetbegovića 20, 75 000, Tuzla (Bosnia and Herzegovina)

Phone: +38761 804941

E-mail: dzevad.mahmutovic@untz.ba

${ }^{2}$ The paper is a part of the research carried out for the purpose of the master's thesis: Huskanović, B. (2017), Uviđaj-krivičnoprocesni $i$ kriminalistički aspekt (unpublished master's thesis), Faculty of Law, University of Tuzla, Tuzla
} 
During the preparation of the paper, a great number of definitions from various regional experts in this field were consulted including: Vodinelić ${ }^{3}$, Vasiljević ${ }^{4}$, Bayer $^{5}$, Modly, Šuperina and Korajlić ${ }^{6}$, Aleksić and Škulić ${ }^{7}$, Pavišić, Modly and Veić ${ }^{8}$, Sijerčić-Čolić ${ }^{9}$ and Bubalović and Pivić ${ }^{10}$. Analyzing their interpretations related to the term 'crime scene investigation', from both criminal-procedural and law enforcement aspect, crime scene investigation can be defined as the evidence-gathering process which is used by crime scene investigators, together with appropriate law enforcement and criminal-procedural matters and their own observations, to scientifically process and document facts that are important for criminal proceedings ${ }^{11}$, i.e. it can be stated that crime scene investigation is the evidence-collecting process which consists of direct observations of changes on-site at a crime ${ }^{12}$ scene inspected by law enforcement.

\footnotetext{
${ }^{3}$ Vodinelić, V. (1977), Revidirani pojam uviđaja-uvjet uspješne forenzične djelatnosti, Jugoslavenska revija za kriminologiju $i$ krivično pravo, 3, p. 82.

${ }^{4}$ Vasiljević T. (1981), Sistem krivičnog procesnog prava SFRJ, treće izmjenjeno i dopunjeno izdanje, Beograd, p. 341.

${ }^{5}$ Bayer V., (1987), Zakon o krivično postupku Jugoslavije, sa komentarom i sudskom praksom, Zagreb, p. 50.

${ }^{6}$ Modly D., Šuperina M. and Korajlić N., (2007), Rječnik kriminalistike, Strukovna udruga kriminalista, Zagreb, p. 494.

${ }^{7}$ Aleksić Ž. and Škulić M. (2011), Kriminalistika (osmo izdanje), Pravni fakultet Univerziteta u Beogradu, Beograd, p. 38

${ }^{8}$ Pavišić B., Modly D. and Veić P. (2006), Kriminalistika (knjiga prva), Golden marketing - Tehnička knjiga, Zagreb, p. 439

${ }^{9}$ Sijerčić-Čolić H. (2012), Krivično procesno pravo (Knjiga I - Krivičnoprocesni subjekti i krivičnoprocesne radnje) - treće izmjenjeno i dopunjeno izdanje, Pravni fakultet Univerziteta u Sarajevu, Sarajevo, p. 413 and Sijerčić-Čolić H., et al. (2005), Komentari krivičnih/kaznenih procesnih zakona, VE, Sarajevo, pp. 273-275
}

${ }^{10}$ Bubalović T. and Pivi N. (2016), Krivično procesno pravo Opći dio, Pravni fakultet univerziteta u Zenici, Zenica, p. 281

${ }^{11 Z ̌ a r k o v c ́ ~ M ., ~ B j e l o v i c ́ ~ I ., ~ K e s i c ́ ~ T ., ~(2012), ~ K r i m i n a l i s t i c ̌ k o ~ p o s t u-~}$ panje na mestu događaja i kredibilitet naučnih dokaza, Beograd, p. 63.

${ }^{12} \mathrm{Crime}$ scene investigation, as an evidence-gathering activity, is not limited to in-situ at a crime scene, and it can be conducted at any other place where with direct observation the investigator can establish facts which are being determined in the investigation. Regarding the places of crime scene investigation, they can be indoors or outdoors depending on a criminal proceeding for which crime scene investigation is conducted. In the case of investigations of indoor crime scene (for example: an apartment), it must be taken into consideration that this evidentiary activity is different from a search of an apartment, because their objectives differ (see more in: SijerčićČolić H., et al. (2005), op.cit., p. 273).
Furthermore, it can be said that crime scene investigation is a system of law enforcement's intellectual, practical and instrumental activities under the Criminal Procedure Code which are, together with criminalistics-technical and tactical methods and means, used to find, preserve from destruction and secure law enforcement and legally-relevant material information (related to objects or traces of crime) for the purpose of potential criminal proceedings.

Also, from their definition of the term 'crime scene investigation', its elements can be determined:

- Crime scene investigation is a system of criminalistics-tactical and technical activities which are conducted in situ at a crime scene under the Criminal Procedure Code and principles of criminalistics,

- Direct sensory observation is achieved on-site at a crime scene by crime scene investigation,

- Finding and analyzing material objects and traces, as well as interpreting criminal activity are accomplished through intellectual activities using planning and verifying criminalistic versions and mental reconstruction of a crime, and

- The entire situation is secured on-site by crime scene investigation.

Therefore, it is wrong to investigate a crime scene only in specific cases depending on the type and gravity of criminal activity. A crime scene needs to be investigated whenever there is any possibility that such practise will enable finding material changes caused by a criminal activity (Žarković et al. 2012, p. 45), i.e. the purpose of crime scene investigation is not only to collect the material for the decision whether to charge or not, but also, in case of pressing charges and presenting the matter at the main hearing, to facilitate the main hearing by the collected evidence which will eliminate unnecessary and useless material from the main hearing ${ }^{13}$.

\section{Subjects participating in crime scene investigation and their cooperation}

Crime scene investigation as an evidentiary activity in a criminal proceeding can be conducted at various stages of a criminal proceeding, and taking that into account, different subjects of a criminal proceeding can participate in an investigation.

\footnotetext{
${ }^{13}$ See more in: Simović M., (2009), Krivičnoprocesno pravo, III izmijenjeno i dopunjeno izdanje, Fakultet za bezbjednost i zaštitu Banja Luka, Banja Luka, p. 316.
} 
Taking into consideration the fact that it is mostly conducted as a pre-investigation and investigation action, the most frequent among them are prosecutors and law enforcement.

Status issues of these bodies in Bosnia and Herzegovina are regulated by specific law on the Prosecutor's Office at the entity and national level, i.e. law on internal affairs at the entity, national and cantonal level. The relationship and cooperation between prosecutors and law enforcement during a criminal proceeding is regulated by a number of provisions contained in Criminal Procedure Code of Bosnia and Herzegovina ${ }^{14}$ and Instruction on the procedure and cooperation between law enforcement and prosecutors in conducting evidentiary activities during the investigation (hereinafter: Instruction) $)^{15}$.

In fact, by the analysis of the existing legislative framework, it can be concluded that the applicable laws on Criminal Procedure Code in Bosnia and Herzegovina offer the basis for the cooperation between prosecutors and law enforcement. However, previous practice indicates certain shortcomings in the cooperation and coordination between prosecutors and law enforcement.

In term of legal regulation, this cooperation is evident in the duty of law enforcement to take the necessary measures if they suspect a criminal offence was committed punishable by a term of imprisonment of at least five years or in case of the postponement risk, in order to find the offender, prevent escape of the suspect or accomplice, discover and secure traces of a criminal activity and objects that can serve as evidence and collect all the information that can be useful in a criminal proceeding. ${ }^{16}$ Law enforcement shall immediately inform the prosecutor on the undertaken action and submit the gathered items that may serve as evidence. ${ }^{17}$

\footnotetext{
${ }^{14}$ Criminal Procedure Code of Bosnia and Herzegovina ("Official Gazette" of Bosnia and Herzegovina nos. 3/03, 32/03, 36/03, 26/04, 63/04, 13/05, 48/05, 46/06, 76/06, 29/07, 32/07, 53/07, 76/07, 15/08, 58/08, 12/09, 16/09, 93/09, 72/13), Articles 35, 218 and analogous provisions of Criminal Procedure Code of the Entities and the District of Brčko.

${ }^{15}$ Adopted by SIPA Director and the Prosecutor General of Bosnia and Herzegovina 12 October 2005 number: 1441/05, Sarajevo.

${ }^{16}$ Criminal Procedure Code of Bosnia and Herzegovina, Article 21, and analogous law articles of the Entities and the District of Brčko.

${ }^{17}$ loc. cit and Instruction on procedure and cooperation of law enforcement (police officers) and the prosecutor in conducting evidentiary activities during the investigation, Article 2
}

The material condition for the mentioned measures by law enforcement is the postponement risk, i.e. the necessity for immediate-urgent action. These are the actions that are by nature unique (as in case of crime scene investigation), but it is necessary to objectively and restrictively interpret the existence of urgency, given that these are exceptions established for the purpose of a proceeding and should not become the rule (Kulić, 2008, pp. 373-401).

Based on the previously mentioned, it can be concluded that from the moment the prosecutor is informed, further activities of law enforcement shall be under the supervision of the prosecutor. ${ }^{18}$ On the other hand, until the moment they inform the prosecutor about a criminal offence, the action of law enforcement is their own responsibility as well as the responsibility of the departments under which they operate (Kulić, 2008, p. 386).

The prosecutor's supervision over the work of law enforcement is reflected in the following:

a) The prosecutor provides professional support and interpretation of the criminal justice regulations, including the substantive and procedural criminal law, and takes into account the application and protection of human rights of citizens during actions conducted by law enforcement, then

b) The prosecutor issues the necessary orders and instructions related to the legal collection of information and evidence to law enforcement during the investigation so that it would be legally valid before the Court, and

c) During the investigation, the prosecutor participates in the necessary actions and other procedures related to the involvement of law enforcement. ${ }^{19}$

The mentioned implies that the relationship between the prosecutor and law enforcement is hierarchical, where the prosecutor is a hierarchical superior that directs the crime scene investigation, whereas law enforcement comply with his orders. That relationship may imply law enforcement's direct action management (direct management of crime scene investigation).

\footnotetext{
${ }^{18}$ Instruction on procedure and cooperation of law enforcement (police officers) and the prosecutor in conducting evidentiary activities during the investigation, Articles 3 and 4

${ }^{19}$ V. Jurčević M. and Huremagić R., (2003), "Uloga tužitelja $u$ istrazi sa posebnim osvrtom na nadzor tužitelja na radom ovlaštenih službenih osoba”, Stručni rad, pp. 227-236,

http://www.tuzilastvobih.gov.ba/files/docs/uloga_tuzitelja_u_istrazi.pdf (accessed on 5 April 2014).
} 
However, in practice, the most frequent one is the prosecutor's supervision over the work of law enforcement, as a more compromising and passive approach which, on the one hand, ensures relative independence (and creativity) in work of law enforcement, while, on the other hand, enables the prosecutor to focus on other activities and at the same time supervise the actions and results of law enforcement. In practical sense, both prosecutors and law enforcement express the shortcomings in their joint actions during crime scene investigation. In informal conversations with prosecutors ${ }^{20}$, with regard to their cooperation, they note:

- Law enforcement issue requests for conducting certain actions without prior consultations with the prosecutor,

- They suggest conducting actions for which they are not materially-equipped and do not have the required staff,

- Due to insufficient education of the prosecutor as well as law enforcement, there are concerns that law enforcement might encourage to criminal activities, without the agreement on how to avoid those situations,

- The insufficient number of law enforcement educated for conducting crime scene investigations, and deficiency in material-technical resources,

- Law enforcement make certain errors in recordkeeping (minutes, issuing certificates, taking statements and collecting evidence, etc.),

- Submitting reports on the activities that are not crime offences to the Prosecutor's Office, which weighs heavily on the work of the Prosecutor's Office.

Law enforcement ${ }^{21}$ are also not completely satisfied with the relationship of the Prosecutor's Office to them, and note the following:

- A lack of active communication between the prosecutor and law enforcement

- Issuing generalized instructions for acting, without going into details,

- Institutional conflicts and a lack of understanding,

- No teamwork,

-Insufficient commitment in planning crime scene investigation by the prosecutor,

\footnotetext{
${ }^{20}$ Interviews with the prosecutors employed in the Cantonal Prosecutor's Office of Canton Tuzla were done in January and February of 2015 at the Municipal Court in Gračanica.

${ }^{21}$ Interviews with law enforcement employed in Police Administration Gračanica, Police Station Gračanica were done between May and July 2015 at the Municipal Court in Gračanica, and one part of interviews was done in April 2016.
}

- Avoiding the submission of certain orders in written form,

- They are not available to law enforcement when they need specific instructions (stand-by duties).

In the absence of research in this area, especially the quantitative one, and with the intention of learning their opinions on the legal regulation and cooperation during crime scene investigation, it has been decided to conduct an empirical research.

The main hypothesis of this paper has been postulated for the purpose of achieving this objective which reads as follows: Adequately and completely legally regulated procedural action of crime scene investigation in the criminal-procedural legislation of Bosnia and Herzegovina leads to successful cooperation between law enforcement and the prosecutor, and in that way contributes to providing high-quality as well as sufficient evidence for a successful conduction of criminal proceedings.

The supporting hypotheses have been proposed, too:

H1: Cooperation between prosecutors and law enforcement needs to be legally regulated,

$\mathrm{H} 2$ : Cooperation between prosecutors and law enforcement is not at the level that might contribute to more efficient and quality conduction of crime scene investigation.

\section{METHODS}

\section{Respondent sample}

The sample consisted of 45 respondents, divided into two subsamples for the purpose of the research. The first deliberately chosen subsample of respondents included prosecutors $(n=15)$ employed in the Cantonal Prosecutor's Office of Canton Tuzla. The other subsample of respondents included law enforcement $(n=30)$, chosen by the method of random selection, who work in Police Administration of Canton Tuzla. Different law enforcement categories participated: police officers, inspectors, and investigators. The sample included respondents of both gender, different professional qualifications in the case of law enforcement as well as different work experience in conducting crime scene investigations. 


\section{Measuring instruments and procedure of conduct- ing research}

The research was conducted using the modified measuring instrument - Questionnaire on procedure and cooperation of the prosecutor and law enforcement in conducting crime scene investigation ${ }^{22}$, which is used for the evaluation of the quality and method of conducting crime scene investigation and the cooperation between the prosecutor and law enforcement. The questionnaire consists of two parts. The first part contains modal independent variables, which cover the data about the sample (institution, i.e. workplace, position in the service, duration of work experience in conducting crime scene investigations and gender). The other part of the questionnaire contains dependent variables which were used to learn the opinions of prosecutors and law enforcement in Tuzla Canton. They are divided to examine the opinions of prosecutors and law enforcement according to the research objectives which are: "Legal regulation and conduction of crime scene investigation" (LEGAL REGULATION) and "Obstacles in the cooperation between the prosecutor and law enforcement in conducting crime scene investigation" (COOPERATION).

The dependent variables were analyzed using estimation scales with a number of statements for which the respondents had to choose one acceptable answer. The answers were distributed using the Likert-type scale, which consisted of five categories.

The research commenced at the beginning of 2014 and ended in 2016. The central part of the research the collection of data by surveying the respondents, ended at the beginning of 2016. Surveying prosecutors and law enforcement was conducted in a way that they were distributed the questionnaires with instructions and filled them by themselves. The survey was anonymous so that the results could be more objective.

\footnotetext{
${ }^{22}$ The measuring instrument is the result of the modification of measuring instruments Questionnaire on procedure and cooperation of law enforcement and the prosecutor in detecting criminal offences and criminal offender and conducting evidentiary activities and Questionnaire on procedure and cooperation of the prosecutor and law enforcement in detecting criminal offences and criminal offender and conducting evidentiary activities, see more in: Sijerčić-Čolić H. and Mahmutović Dž., (2014), Prepreke za otkrivanje $i$ dokazivanje krivičnih djela i efikasno odvijanje istrage - Rezultati empirijskog istraživnja u Bosni $i$ Hercegovini, Pravo i pravda, godine XIII, no. 1, Sarajevo, pp. 243-264
}

\section{Data processing methods}

The research data were processed using the descriptive analysis. In the first phase, the distribution of frequencies and answer percentages for all statements were determined using the obtained data. The summary of the data for certain variables was done in the second phase, and, based on the total result, basic statistical parameters were calculated including: arithmetic mean, standard deviation, minimum, maximum, and sum. With regard to the type of data, sample size and normality of distribution, the Mann-Whitney $U$ test was used to evaluate the differences of mean values for two dependant variables (LEGAL REGULATION and COOPERATION) of prosecutors and law enforcement. The Pearson correlation coefficient was measured to determine the connection between work experience and dependent variables. The data collected during the research were processed using the software package SPSS for Windows.

\section{RESULTS AND DISCUSSION}

\section{Frequencies and percentages of the research results for the variables of crime scene investigation pro- cess}

Table 1 indicates distribution of frequencies and percentages of the answers given by prosecutors when expressing their agreement with the statements for the variable "Legal regulation and conduction of the process of crime scene investigation" (LEGAL REGULATION). When the coding of answers is taken into consideration, the tendency is visible of positive opinions for most statements referring to the legal regulation and conduction of crime scene investigation. In over $90 \%$ of the answers, the respondents completely or mainly agree with the statements that positively assess the legal regulation and conduction of crime scene investigation while over $60 \%$ of them completely or mainly disagree with the statements that negatively assess the legal regulation and conduction of crime scene investigation. For four statements that additionally check the cooperation between prosecutors and law enforcement (Cooperation between prosecutors and law enforcement needs to be legally regulated, Better communication is needed between prosecutors and law enforcement, There is distrust, misunderstanding and professional disrespect between the prosecutor and the law enforcement officer, and I find personal cooperation with the prosecutor/authorized law enforcement officers successful), negative opinions are evident. 
In terms of answer coding, most prosecutors completely or mainly agree with the statements while a significant percentage is indecisive.

The prosecutors had different opinions towards the statement There is appropriate education of law en- forcement officers in charge of crime scene investigation in criminal cases. This is evident from the equally distributed answers (agreement and disagreement) related to this statement.

Table 1 Distribution of frequencies and percentages of answers for the variable LEGAL REGULATION - prosecutors

\begin{tabular}{|c|c|c|c|c|c|c|c|c|c|c|}
\hline \multirow{2}{*}{ LEGAL REGULATION } & \multicolumn{2}{|c|}{$\begin{array}{c}\text { Completely } \\
\text { agree }\end{array}$} & \multicolumn{2}{|c|}{$\begin{array}{c}\text { Mainly } \\
\text { agree }\end{array}$} & \multicolumn{2}{|c|}{ Indecisive } & \multicolumn{2}{|c|}{$\begin{array}{c}\text { Mainly } \\
\text { disagree }\end{array}$} & \multicolumn{2}{|c|}{$\begin{array}{c}\text { Completely } \\
\text { disagree }\end{array}$} \\
\hline & $\mathbf{f}$ & $\%$ & f & $\%$ & $\mathbf{f}$ & $\%$ & f & $\%$ & f & $\%$ \\
\hline $\begin{array}{l}\text { Appropriate measures and activities of } \\
\text { law enforcement }\end{array}$ & 1 & 6.7 & 14 & 93.3 & 0 & .0 & 0 & .0 & 0 & 0,0 \\
\hline $\begin{array}{l}\text { Appropriate role of the prosecutor/law } \\
\text { enforcement officer }\end{array}$ & 9 & 60.0 & 6 & 40.0 & 0 & .0 & 0 & .0 & 0 & 0,0 \\
\hline $\begin{array}{l}\text { Prosecutor has sufficient knowledge in } \\
\text { criminology }\end{array}$ & 5 & 33.3 & 8 & 53.3 & 0 & .0 & 2 & 13.3 & 0 & .0 \\
\hline $\begin{array}{l}\text { The process of crime scene } \\
\text { investigation is appropriately legally } \\
\text { regulated }\end{array}$ & 1 & 6.7 & 13 & 86.7 & 0 & .0 & 0 & .0 & 1 & 6.7 \\
\hline $\begin{array}{l}\text { Cooperation between prosecutors and } \\
\text { law enforcement needs to be legally } \\
\text { regulated }\end{array}$ & 6 & 40.0 & 8 & 53.3 & 1 & 6.7 & 0 & .0 & 0 & .0 \\
\hline $\begin{array}{l}\text { I give/receive instructions on taking } \\
\text { activities of crime scene investigation }\end{array}$ & 9 & 60.0 & 5 & 33.3 & 1 & 6.7 & 0 & .0 & 0 & .0 \\
\hline $\begin{array}{l}\text { Crime scene investigation takes too } \\
\text { long }\end{array}$ & 0 & .0 & 2 & 13.3 & 1 & 6.7 & 10 & 66,7 & 2 & 13,3 \\
\hline $\begin{array}{l}\text { Quality of crime scene investigation is } \\
\text { satisfactory }\end{array}$ & 4 & 26.7 & 11 & 73.3 & 0 & .0 & 0 & .0 & 0 & .0 \\
\hline $\begin{array}{l}\text { Better communication is needed } \\
\text { between prosecutors and law } \\
\text { enforcement }\end{array}$ & 8 & 53.3 & 6 & 40.0 & 0 & .0 & 1 & 6.7 & 0 & .0 \\
\hline $\begin{array}{l}\text { Existing regulations cause } \\
\text { misunderstanding between } \\
\text { prosecutor's office and law } \\
\text { enforcement }\end{array}$ & 0 & .0 & 2 & 13.3 & 3 & 20.0 & 9 & 60.0 & 1 & 6.7 \\
\hline $\begin{array}{l}\text { Existing regulations cause } \\
\text { inappropriate reaction of law } \\
\text { enforcement }\end{array}$ & 0 & .0 & 0 & .0 & 5 & 33.3 & 9 & 60.0 & 1 & 6.7 \\
\hline $\begin{array}{l}\text { There is distrust, misunderstanding } \\
\text { and professional disrespect between } \\
\text { the prosecutor and the law } \\
\text { enforcement officer }\end{array}$ & 1 & 6.7 & 4 & 26.7 & 4 & 26.7 & 6 & 40.0 & 0 & .0 \\
\hline $\begin{array}{l}\text { There is appropriate education of law } \\
\text { enforcement officers in charge of } \\
\text { crime scene investigation in criminal } \\
\text { cases }\end{array}$ & 0 & .0 & 3 & 20.0 & 7 & 46.7 & 4 & 26.7 & 1 & 6.7 \\
\hline $\begin{array}{l}\text { I find personal cooperation with the } \\
\text { prosecutor/authorized law } \\
\text { enforcement officers successful }\end{array}$ & 2 & 13.3 & 5 & 33.3 & 7 & 46.7 & 1 & 6.7 & 0 & .0 \\
\hline
\end{tabular}

Table 2 shows distribution of frequencies and percentages of answers given by law enforcement, when expressing their agreement with the statements for the variable LEGAL REGULATION. For all the statements related to legal regulation and crime scene investigation, these respondents gave similar affirmative answers as did the prosecutors, with slightly more indecisive answers.
When it comes to the statement There is appropriate education of law enforcement officers in charge of crime scene investigation in criminal cases, law enforcement officers mainly expressed negative opinions and over $70 \%$ of them completely or mainly disagree with this statement. 
Table 2 Distribution of frequencies and percentages of answers for the variable LEGAL REGULATION - law enforcement

\begin{tabular}{|c|c|c|c|c|c|c|c|c|c|c|}
\hline \multirow[t]{2}{*}{ LEGAL REGULATION } & \multicolumn{2}{|c|}{$\begin{array}{c}\text { Completely } \\
\text { agree }\end{array}$} & \multicolumn{2}{|c|}{$\begin{array}{c}\text { Mainly } \\
\text { agree }\end{array}$} & \multicolumn{2}{|c|}{ Indecisive } & \multicolumn{2}{|c|}{$\begin{array}{c}\text { Mainly } \\
\text { disagree }\end{array}$} & \multicolumn{2}{|c|}{$\begin{array}{c}\text { Completely } \\
\text { disagree }\end{array}$} \\
\hline & f & $\%$ & f & $\%$ & f & $\%$ & $\mathbf{f}$ & $\%$ & f & $\%$ \\
\hline $\begin{array}{l}\text { Appropriate measures and activities of law } \\
\text { enforcement }\end{array}$ & 21 & 70.0 & 9 & 30.0 & 0 & .0 & 0 & .0 & 0 & .0 \\
\hline $\begin{array}{l}\text { Appropriate role of the prosecutor/law enforcement } \\
\text { officer }\end{array}$ & 16 & 53.3 & 10 & 33.3 & 2 & 6.7 & 2 & 6.7 & 0 & .0 \\
\hline $\begin{array}{l}\text { Prosecutor has sufficient knowledge in } \\
\text { criminology }\end{array}$ & 3 & 10.0 & 10 & 33.3 & 13 & 43.3 & 4 & 13.3 & 0 & .0 \\
\hline $\begin{array}{l}\text { The process of crime scene investigation is } \\
\text { appropriately legally regulated }\end{array}$ & 6 & 20.0 & 18 & 60.0 & 4 & 13.3 & 1 & 3.3 & 1 & 3.3 \\
\hline $\begin{array}{l}\text { Cooperation between prosecutors and law } \\
\text { enforcement needs to be legally regulated }\end{array}$ & 16 & 53.3 & 11 & 36.7 & 1 & 3.3 & 2 & 6.7 & 0 & .0 \\
\hline $\begin{array}{l}\text { I give/receive instructions on taking activities of } \\
\text { crime scene investigation }\end{array}$ & 8 & 26.7 & 17 & 56.7 & 2 & 6.7 & 3 & 10.0 & 0 & .0 \\
\hline Crime scene investigation takes too long & 0 & .0 & 0 & .0 & 11 & 36.7 & 10 & 33.3 & 9 & 30.0 \\
\hline Quality of crime scene investigation is satisfactory & 6 & 20.0 & 11 & 36.7 & 11 & 36.7 & 2 & 6.7 & 0 & .0 \\
\hline $\begin{array}{l}\text { Better communication is needed between } \\
\text { prosecutors and law enforcement }\end{array}$ & 17 & 56.7 & 10 & 33.3 & 1 & 3.3 & 2 & 6.7 & 0 & .0 \\
\hline $\begin{array}{l}\text { Existing regulations cause misunderstanding } \\
\text { between prosecutor's office and law enforcement }\end{array}$ & 5 & 16.7 & 7 & 23.3 & 10 & 33.3 & 6 & 20.0 & 2 & 6.7 \\
\hline $\begin{array}{l}\text { Existing regulations cause inappropriate reaction of } \\
\text { law enforcement }\end{array}$ & 3 & 10.0 & 5 & 16.7 & 7 & 23.3 & 10 & 33.3 & 5 & 16.7 \\
\hline $\begin{array}{l}\text { There is distrust, misunderstanding and } \\
\text { professional disrespect between the prosecutor and } \\
\text { the law enforcement officer }\end{array}$ & 3 & 10.0 & 7 & 23.3 & 7 & 23.3 & 6 & 20.0 & 7 & 23.3 \\
\hline $\begin{array}{l}\text { There is appropriate education of law enforcement } \\
\text { officers in charge of crime scene investigation in } \\
\text { criminal cases }\end{array}$ & 1 & 3.3 & 2 & 6,7 & 5 & 16,7 & 10 & 33,3 & 12 & 40.0 \\
\hline $\begin{array}{l}\text { I find personal cooperation with the } \\
\text { prosecutor/authorized law enforcement officers } \\
\text { successful }\end{array}$ & 5 & 16.7 & 10 & 33,3 & 13 & 43,3 & 2 & 6,7 & 0 & .0 \\
\hline
\end{tabular}

Graph 1 brings the visual comparative presentation of the percentage share of the total answers given by the respondents for the statements related to the variable LEGAL REGULATION. When compared to the tables, the graph clearly indicates that out of five meas-

urement categories, according to answer coding, most frequent answers in both subsamples of the respondents were "Completely agree" and "Mainly agree", which mostly reflect positive opinions towards the statements for this variable.

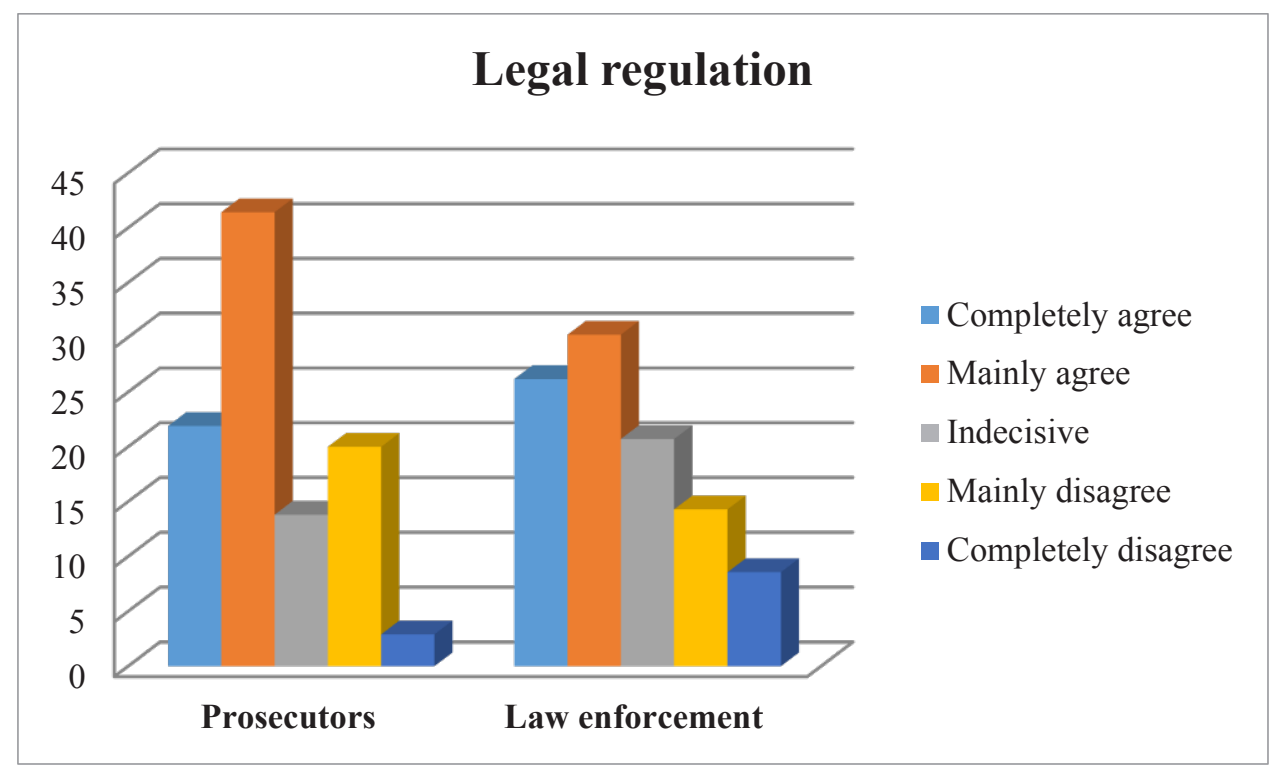

Graph 1 Percentage of the total answers for the variable LEGAL REGULATION 
Table 3 shows distribution of frequencies and percentages of answers given by prosecutors when stating their agreement with the statements for the variable "Obstacles to cooperation between the prosecutor and law enforcement during the process of crime scene investigation" (COOPERATION). In terms of answer coding, there is a tendency of positive opinions as most answers given were "Partly affects" and "Does not affect" (over 50\%), except for the statement Inadeuqate investigating abilities, where nega- tive opinions were expressed in over $70 \%$ of the cases with the answers "Criticially affects" and "Rather affects". Based on such opinions of the prosecutors, it is evident that apart from inadequate investigating abilities, there are no other obstacles significantly affecting cooperation between the prosecutor and law enforcement during crime scene investigation process. However, a certain percentage of negative opinions for other statements still indicates that this cooperation should be improved.

Table 3 Distribution of frequencies and percentages of answers for the variable COOPERATION-prosecutors

\begin{tabular}{|c|c|c|c|c|c|c|c|c|c|c|}
\hline \multirow[t]{2}{*}{ COOPERATION } & \multicolumn{2}{|c|}{$\begin{array}{l}\text { Critically } \\
\text { affects }\end{array}$} & \multicolumn{2}{|c|}{$\begin{array}{l}\text { Rather } \\
\text { affects }\end{array}$} & \multicolumn{2}{|c|}{$\begin{array}{l}\text { Mainly } \\
\text { affects }\end{array}$} & \multicolumn{2}{|c|}{ Partly affects } & \multicolumn{2}{|c|}{$\begin{array}{c}\text { Does not } \\
\text { affect }\end{array}$} \\
\hline & $\mathbf{f}$ & $\%$ & $\mathbf{f}$ & $\%$ & $\mathbf{f}$ & $\%$ & $\mathbf{f}$ & $\%$ & $\mathbf{f}$ & $\%$ \\
\hline Inadequate investigating abilities & 8 & 53.3 & 3 & 20.0 & 2 & 13.3 & 2 & 13.3 & 0 & .0 \\
\hline No joint training organized & 0 & .0 & 5 & 33.3 & 2 & 13.3 & 5 & 33.3 & 3 & 20.0 \\
\hline $\begin{array}{llll}\text { Insufficient } & \text { number } & \text { of } & \text { law } \\
\text { enforcement } & & & \\
\end{array}$ & 1 & 6.7 & 3 & 20.0 & 4 & 26.7 & 4 & 26.7 & 3 & 20.0 \\
\hline $\begin{array}{l}\text { Inappropriate legal regulation of the } \\
\text { process of crime scene investigation }\end{array}$ & 1 & 6.7 & 1 & 6.7 & 3 & 20.0 & 6 & 40.0 & 4 & 26.7 \\
\hline Other & 0 & .0 & 1 & 6.7 & 0 & .0 & 4 & 26.7 & 10 & 66.7 \\
\hline
\end{tabular}

Table 4 indicates distribution of frequencies and percentages of the answers given by law enforcement when expressing their agreement with the statements for the variable COOPERATION. Somewhat different answers are evident for this group of respondents when compared to the answers given by prosecutors. Most answers are neutral with the tendency towards positive opinions. In other words, most answers given by the respondents are distributed into the categories "Partly affects" and "Mainly affects" (over 60\% of the answers for four statements) and over $90 \%$ for the statement "Other", which undoubtedly confirms positive opinions.

Based on such opinions of law enforcement, it is evident that there are almost no obstacles significantly affecting cooperation between the prosecutor and law enforcement during crime scene investigation process. However, a certain percentage of negative opinions of law enforcement for all the statements still indicates that this cooperation might be better.

Table 4 Distribution of frequencies and percentages of answers for the variable COOPERATION- law enforcement

\begin{tabular}{|c|c|c|c|c|c|c|c|c|c|c|}
\hline \multirow[t]{2}{*}{ COOPERATION } & \multicolumn{2}{|c|}{$\begin{array}{l}\text { Critically } \\
\text { affects }\end{array}$} & \multicolumn{2}{|c|}{$\begin{array}{l}\text { Rather } \\
\text { affects }\end{array}$} & \multicolumn{2}{|c|}{$\begin{array}{l}\text { Mainly } \\
\text { affects }\end{array}$} & \multicolumn{2}{|c|}{$\begin{array}{l}\text { Partly } \\
\text { affects }\end{array}$} & \multicolumn{2}{|c|}{$\begin{array}{c}\text { Does not } \\
\text { affect }\end{array}$} \\
\hline & $\mathbf{f}$ & $\%$ & $\mathbf{f}$ & $\%$ & $\mathbf{f}$ & $\%$ & f & $\%$ & $\mathbf{f}$ & $\%$ \\
\hline Inadequate investigating abilities & 3 & 10.0 & 1 & 3.3 & 7 & 23.3 & 13 & 43.3 & 6 & 20.0 \\
\hline No joint training organized & 2 & 6.7 & 6 & 20.0 & 10 & 33.3 & 11 & 36.7 & 1 & 3.3 \\
\hline Insufficient number of law enforcement & 5 & 16.7 & 5 & 16.7 & 11 & 36.7 & 7 & 23.3 & 2 & 6.7 \\
\hline $\begin{array}{l}\text { Inappropriate legal regulation of the process of crime } \\
\text { scene investigation }\end{array}$ & 2 & 6.7 & 3 & 10.0 & 8 & 26.7 & 14 & 46.7 & 3 & 10.0 \\
\hline Other & 0 & .0 & 0 & .0 & 0 & .0 & 3 & 10 & 27 & 90.0 \\
\hline
\end{tabular}


Graph 2 brings the visual comparative presentation of the percentage share of the total answers given by the respondents for the statements related to the variable COOPERATION. When compared to the tables, the graph clearly indicates that out of five measurement categories, according to answer coding, most frequent answers in both subsamples of the respondents were "Partly affects" and "Does not affect", which mostly reflect positive opinions towards the statements for this variable.

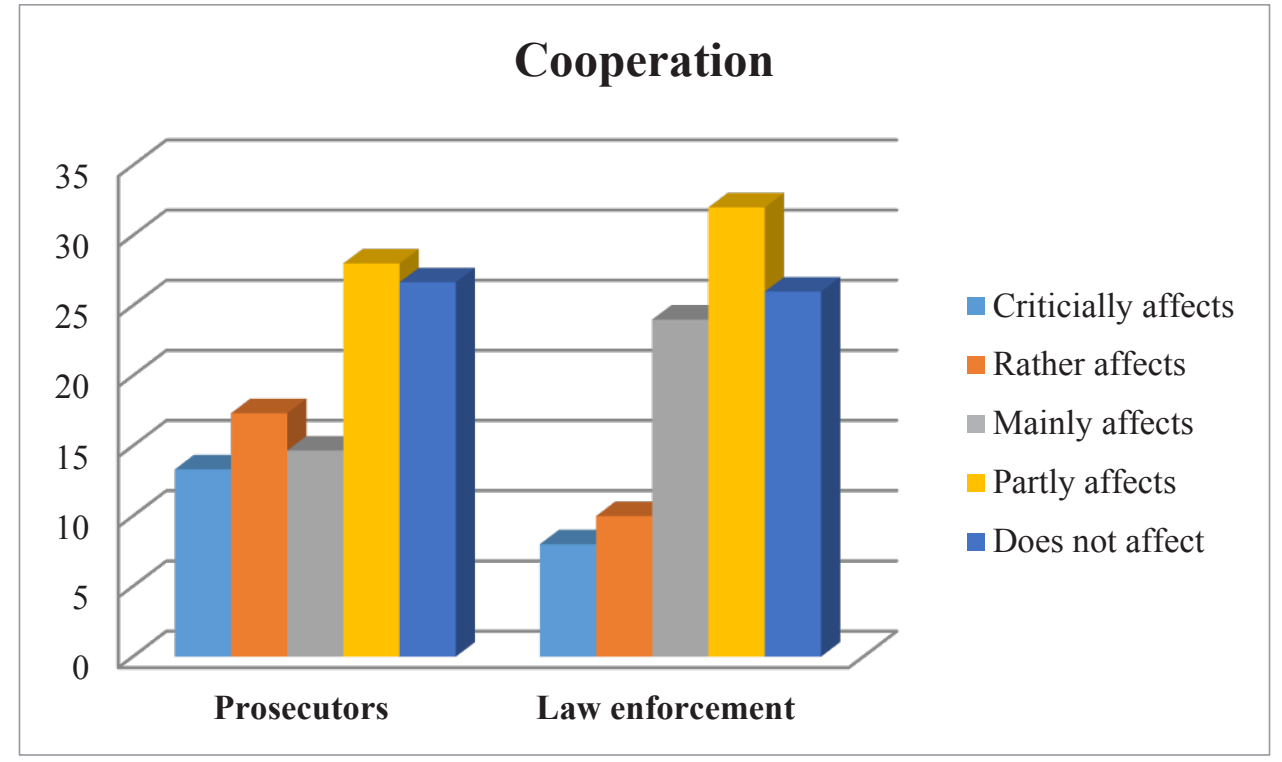

Graph 2 Percentage of the total answers for the variable COOPERATION

Basic statistical parameters of the research results for the variables related to crime scene investigation

The fact that the sample included two subsamples (prosecutors and law enforcement) with different roles the respondents have during crime scene investigation served to justify the argumentation of differ- ences in the opinions of these subsamples for the total results for the variables LEGAL REGULATION and COOPERATION.

Table 5 presents the basic statistical parameters and gives evidence to certain differences in these parameters for both variables, which was evident in individual results through the distribution of frequencies and percentages.

Table 5 Basic statistical parameters of the results for the opinions of prosecutors and law enforcement

\begin{tabular}{lcccccc}
\hline \multicolumn{1}{c}{ Variables } & Sample & Min & Max & M & SD & Sum \\
\hline \multirow{2}{*}{ Legal regulation } & Prosecutors & 41 & 54 & 50.0 & 3.96 & 752 \\
& Law enforcement & 41 & 62 & 49.0 & 5.05 & 1470 \\
\hline \multirow{2}{*}{ Cooperation } & Prosecutors & 9 & 21 & 13.1 & 3.80 & 197 \\
& Law enforcement & 5 & 17 & 12.1 & 2.96 & 340 \\
\hline
\end{tabular}

Mann-Witney $U$ test of the differences in the research results for the variables regarding the conduction of crime scene investigation

As the descriptive analysis showed certain differences between the subsamples of prosecutors and law enforcement for the variables used to examine the opinions on legal regulation and conduction of crime scene investigation, the Mann-Witney U test was used to check the statistical significance of these differences. It was established that there is not statistically significant difference for the variables LEGAL REGULATION and COOPERATION. 
Table 6 Mann-Witney U test of the differences in answers given by prosecutors and law enforcement

\begin{tabular}{lccccccc}
\hline \multicolumn{1}{c}{ Variables } & Protocol & Mean Rank & Sum of Ranks & Median & $\begin{array}{c}\text { Mann- } \\
\text { Whitney U }\end{array}$ & Z & Sig. \\
\hline Legal regulation & Prosecutor & 26.60 & 399.00 & 51.00 & 171.00 & -1.31 & .19 \\
& Law enforcement & 21.20 & 636.00 & 48.50 & & & \\
\hline Cooperation & Prosecutor & 23.93 & 359.00 & 11.00 & 211.00 & -.34 & .74 \\
& Law enforcement & 22.53 & 676.00 & 11.50 & & & \\
\hline
\end{tabular}

Correlation of variables regarding the conduction of crime scene investigation

Besides confirming the differences, there was also a need for examining the correlation between the years of work experience in the service and the variables that define the respondents' opinions towards the conduction of crime scene investigation (LEGAL REGULATION, COOPERATION). The results of the Pearson correlation coefficient, determined for the entire sample of the respondents, indicate that there is no correlation between the length of work experience and other variables. This means that the years of work experience of prosecutors and law enforcement do not significantly affect the opinions regarding the conduction of crime scene investigation, which additionally confirms the above presented research results (Table 7).

Table 7 Correlation of variables related to the conduction of crime scene investigation

\section{Legal regulation}

\section{Cooperation}

\begin{tabular}{llcc}
\hline Length of work & $\mathbf{r}$ & -.194 & -.152 \\
experience & $\mathbf{p}$ & .201 & .320 \\
\hline
\end{tabular}

The obtained reserch results confirm the hypotheses "Cooperation between prosecutors and law enforcement needs to be legally regulated" and "Cooperation between prosecutors and law enforcement is not at the level that might contribute to more efficient and quality conduction of crime scene investigation" as the negative opinions were registered and according to answer coding most respondents "completely agree" or "mainly agree" with the statements along with a significant percentage of undecisive answers. Still, we should not undermine the results that indicate that cooperation might be better and that it should be imporoved.

The main hypothesis of the paper, "Adequately and completely legally regulated procedural action of crime scene investigation in the criminal-procedural legislation of Bosnia and Herzegovina leads to successful cooperation between law enforcement and the prosecutor, and in that way contributes to providing high-quality as well as sufficient evidence for a successful conduction of criminal proceedings." can thus be confirmed.

\section{CONCLUSION}

Furthermore, it can be said that crime scene investi- gation is a system of law enforcement's intellectual, practical and instrumental activities under the Criminal Procedure Code which are, together with criminalistics-technical and tactical methods and means, used to find, preserve from destruction and secure law enforcement and legally-relevant material information (related to objects or traces of crime) for the purpose of potential criminal proceedings.

Crime scene investigation as an evidentiary activity in a criminal proceeding can be conducted at various stages of a criminal proceeding, and taking that into account, different subjects of a criminal proceeding can participate in an investigation. Taking into consideration the fact that it is mostly conducted as a pre-investigation and investigation action, the most frequent among them are prosecutors and law enforcement.

Their relationship and cooperation are of vital interest for successful carrying out this activity. The analysis of the existing legal framework leads to the conclusion that the current criminal procedure codes in $\mathrm{BiH}$ provide the appropriate basis for the cooperation of prosecutors and law enforcement. However, previous practice indicates certain shortcomings in the cooperation and coordination between the prosecutors and law enforcement. 
The research shows that prosecutors are somewhat dissatisfied by the relationship the prosecutor-law enforcement. The results indicate that over $70 \%$ of the prosecutors believe one of the main obstacles in cooperation between the prosecutor and law enforcement in conducting crime scene investigation to be inadequate investigating abilities of law enforcement. On the other hand, the research showed that most answers given by law enforcement are neutral with the tendency towards positive opinions. Most of their opinions are evidently positive, which leads to the conclusion that there are almost no obstacles significantly affecting cooperation between the prosecutor and law enforcement in conducting crime scene investigation. However, a minor percentage of negative answers of law enforcement is present for all the statements, which suggests that cooperation might be better.

When these research results are considered, the research should be continued with the focus on the definition of the main directions for the improvement of the legal regulation framework and cooperation between prosecutors and law enforcement during crime scene investigation.

\section{REFERENCES}

Aleksić Ž. and Škulić M. (2011). Kriminalistika (osmo izdanje), Pravni fakultet Univerziteta u Beogradu, Beograd

Bayer V., (1987). Zakon o krivično postupku Jugoslavije, sa komentarom i sudskom praksom, Zagreb, p. 50

Bubalović T. and Pivič N. (2016). Krivično procesno pravo Opći dio, Pravni fakultet Univerziteta u Zenici, Zenica

Huskanović, B. (2017). Uviđaj - krivičnoprocesni $i$ kriminalistički aspekt (neobjavljeni završni magistarski rad), Pravni Fakultet Univerziteta u Tuzli, Tuzla

Jurčević M. and Huremagić R., (2003). ,Uloga tužitelja u istrazi sa posebnim osvrtom na nadzor tužitelja na radom ovlaštenih službenih osoba “, Stručni rad http://www.tuzilastvobih.gov.ba/files/docs/uloga_tuzitelja_u_istrazi.pdf (accessed 5 April 2014)

Kulić D. (2008). „Ovlašteno službeno lice kao subjekat istrage u krivičnoprocesnom zakonodavstvu Bosne i Hercegovine", Pravna riječ, 15/2008, Banja Luka

Milidragović, D. (2008). Kriminalistički i krivično-procesni aspekti u vršenju uviđaja na području grada Novog Sada, Bezbednost, Teorijsko stručni časopis Ministarstva unutrašnjih poslova Republike Srbije, no. 1-2, Beograd

Modly D., Šuperina M. and Korajlić N., (2007). Rječnik kriminalistike, Strukovna udruga kriminalista, Zagreb

Pavišić B., Modly D. and Veić P. (2006). Kriminalistika (knjiga prva), Golden marketing - Tehnička knjiga, Zagreb

Petrović, B. (2006). Uvod u kriminalistiku, Fakultet kriminalističkih nauka Univerziteta u Sarajevu, Priština

Sijerčić-Čolić H. (2012). Krivično procesno pravo (Knjiga I - Krivičnoprocesni subjekti $i$ krivičnoprocesne radnje) - treće izmjenjeno i dopunjeno izdanje, Pravni fakultet Univerziteta u Sarajevu, Sarajevo

Sijerčić-Čolić H., etal. (2005). Komentari krivičnih/kaznenih procesnih zakona, VE, Sarajevo

Sijerčić-Čolić H. and Mahmutović Dž., (2014). Prepreke za otkrivanje i dokazivanje krivičnih djela i efikasno odvijanje istrage - Rezultati empirijskog istraživnja u Bosni i Hercegovini, Pravo i pravda, godine XIII, no. 1, Sarajevo

Simović M., (2009). Krivičnoprocesno pravo, III izmijenjeno $i$ dopunjeno izdanje, Fakultet za bezbjednost i zaštitu Banja Luka, Banja Luka

Upustvo o postupanju i saradnji ovlaštenih službenih osoba (policijskih službenika) i tužioca u provođenju radnji dokazivanja u toku istrage

Vasiljević T. (1981). Sistem krivičnog procesnog prava SFRJ, treće izmjenjeno i dopunjeno izdanje, Beograd

Vodinelić, V. (1977). Revidirani pojam uviđaja - uvjet uspješne forenzične djelatnosti, Jugoslavenska revija za kriminologiju i krivično pravo, 3

Criminal Procedure Code of Bosnia and Herzegovina, Official Gazzette of Bosnia and Herzegovina, nos. 3/03, 32/03, 36/03, 26/04, 63/04, 13/05, 48/05, 46/06, 76/06, 29/07, $32 / 07,53 / 07,76 / 07,15 / 08,58 / 08,12 / 09,16 / 09,93 / 09$, $72 / 13$

Žarkovć M., Bjelović I., Kesić T., (2012). Kriminalističko postupanje na mestu događaja i kredibilitet naučnih dokaza, Beograd 